\title{
Anthropometric measurement of the hand
}

\author{
Nuriye Kübra Bayraktar ${ }^{1}$, Esin Özşahin ${ }^{2 *}$ \\ ${ }^{1}$ Baskent University Adana Vocational High School Of Health Medical Imaging, Adana, Turkey \\ ${ }^{2}$ Baskent University, Faculty of Medicine, Department of Anatomy, Adana, Turkey
}

\begin{abstract}
This study aims to get various anthropometric measurements of dominant hands of students from vocational high school of health and classifies them according to Krogman Hand Index to form a database

141 students (49 male, 92 female) who were healthy anatomically and had no other known disease attending to vocational high school of health of Baskent University were recruited. Right hand was dominant for all of the students. The length and width of the right hand of the students were taken after their height and weight were measured. The results were recorded as mm. The findings were classified according to Krogman index with the formula hand width / hand lengt X 100.

For males right hand length and width was $183.9 \pm 0.88 \mathrm{~mm}$; and $87.54 \pm 0.70 \mathrm{~mm}$; respectively, with hand index being 47.58 and classified as brachyeri according to Krogman hand index. For females, right hand length and width was $169.75 \pm 2.01$ and $77.63 \pm 1.21 \mathrm{~mm}$ respectively with hand index being 45.72 and classified as mesocheri according to Krogman hand index.

Measurements of body and body parts display variability due to age, gender, genetic and environmental factors across populations. Therefore; such data used in gender discrimination, identification and special ergonomic structures need to be population spesific.
\end{abstract}

Key Words: Right hand width, right hand length, hand index, Krogman index

\section{Introduction}

The hand is presented in a large area in cerebral cortex and controlled by a rich nerve network and it is like a psychologic, physicologic and aesthetic extention of the brain. The hand has a number of important functions like perception, management and self expression (1). With its nerve and vessel packages, channels and tunnels and musculosceletal components like ligaments, tendons and facias the hand has a unique biomechanic and architectural design (2). That the hand gets injured in $1 / 3$ of industrial accidents reflects its functional importance. Besides; permanent damages occur in half of accidents. Some anthropologists believe that the hand causes the inconceivable development of the brain. In fact; the hand has been of great help for the formation of civilization, and to humankind for effectively changing his environment. The hand is open to traumas and gets widely affected in the course of diseases. $31 \%$ of all injuries affect upper extremity and $1 / 3$ of these end up with an anatomic or a functional loss of the hand. $(3,4,5,6)$. Besides all these clinical significances the hand helps draw a roadmap for gender and height prediction of people.

Determination of gender and height are important criteria for personal identification. Assessments regarding to age, gender, height and race can be made through anthropometric methods $(7,8)$. Before DNA studies were performed for personal identification, anthropometric measurements (although they did not provide precise results) were widely used and when combined with other techniques they reduced the pool of people for identification which was helpful by way of human resources and money. These methods are beneficial when they are modified for a given society. Methods and regression formulas built for a single society may not be suitable for another (9). In mass deaths and criminologic cases identification of human remains is an important struggle for forensic experts $(10,11,12)$. Valuable data can be provided about the height and gender of someone with the use of morphometric features. Determination of hand morphometry and the data obtained at the end can help build a database regarding to various populations. It can also support scientific studies and provide a valuable source of reference for scientists.

\section{Material and Methods}

141 students (49 male, 92 female) who were healthy anatomically and had no other known disease attending to vocational high school of health of Baskent University were recruited. Right hand was dominant for all of the students. The length and width of the right hand of the students were taken after their height and weight were measured. The results were recorded as $\mathrm{mm}$. The findings were 
Table 1. The means, standard deviations and ranges of the parameters of the males and females

\begin{tabular}{lcccc}
\hline & \multicolumn{2}{c}{ Males $(\mathrm{n}=49)$} & \multicolumn{2}{c}{ Females $(\mathrm{n}=92)$} \\
\cline { 2 - 5 } Parameters & Range & Mean \pm SD & Range & Mean \pm SD \\
\hline Age (year) & $(18-30)$ & $20.0 \pm 3.3$ & $(17-30)$ & $20.0 \pm 2.6$ \\
BMI (kg/m2) & $(16.7-37.6)$ & $24.5 \pm 4.0$ & $(16.3-68.4)$ & $21.3 \pm 5.9$ \\
Hand Length (mm) & $(153.2-199.4)$ & $183.9 \pm 0.8$ & $(115.1-332.5)$ & $169.7 \pm 2.01$ \\
Hand Width (mm) & $(579.0-996.0)$ & $87.5 \pm 7.7$ & $(126.0-917.0)$ & $76.3 \pm 12.1$ \\
\hline
\end{tabular}

classified according to Krogman index with the formula hand width/hand length X 100. This study has been approved by Baskent University Ethics Comittee and supported by Baskent University Research Fund. In literature it is stated that measurements on dominant hand of a person gave more objective results. Therefore the measurements were taken from the right hand. After age, gender, height and weight of the students were taken, the hands were placed on a flat surface with fingers fully extended and the measurements were taken when the interphalangial and metacarpophalangial joint angles were 180 at the anatomical stand posture. Hand length and hand width of the students were taken consequtively. The anatomical landmarks for measurements were:

Hand Length: It is the length taken between the highest point of the middle finger and the intersection of the midpoints of radial and ulnar notches. (Figure 1.)

Hand Width: It is the length between distal points of 2 and 5 metacarps Measurements were recorded as $\mathrm{mm}$. The results were calculated according to the formula Hand Index $=$ Hand width/Hand length $\mathrm{x} 100$ and classified according to standart Krogman Index(3). ( Figure 2).

\section{Standart Krogman Index:}

$\begin{array}{lc}\text { Hyperdolichocheri } & \mathrm{x}-40.9 \\ \text { Dolichocheri } & 41.0-43.9 \\ \text { Mesocheri } & 44.0-46.9 \\ \text { Brachycheri } & 47.0-49.9 \\ \text { Hyperbrachycheiri } & 50.0-\mathrm{x}\end{array}$

\section{Results}

Mean valves of body mass index (BMI) was found to be $24.5 \pm 4.0 \mathrm{~kg} / \mathrm{m}^{2}$ for males and $21.3 \pm 5.9 \mathrm{~kg} / \mathrm{m}^{2}$ for females. The average length of the right hand was $183.9 \pm 0.8 \mathrm{~mm}$ and $169.7 \pm 2.0 \mathrm{~mm}$ for males and females respectively. The average width of the right hand was $87.5 \pm 0.7 \mathrm{~mm}$ and $77.6 \pm 1.2 \mathrm{~mm}$ for males and females respectively, and the hand index was 47.5 for males and 45.7 for females. According to the
Krogman hand index, the males are classified as bracycheri and the females as mesocheri (Table 1).

\section{Discussion}

Measurements of body and body parts and their association with age and gender are quite variable due to genetic and environmental factors across populations (3). Therefore, these types of data that are thought to be used in personal ergonomic designs for gender verification and identification, are suggested to be population-specific (7).

This study with many similar ones have displayed that there are differences regarding hand dimensions across communities (2-12-15). In literature, there are researches that have taken left hand or right hand measurements, and there are some that have taken both (14). When the latter is taken into account, it is reported that the association between both hand dimensions and height is studied. Agnihotri et al. (11) have reported that left hand length was associated with height prediction more than the right hand. On the other hand, Onat et al. (15) have stated in their report that the left hand length is greater than the right hand in both genders. In this study, we have made our measurements on cases that have their right hands dominant.

A review of literature shows that there are limited of studies for the identification of hand morphometry. Most of the researches on this subject are specific to Asian and African communities. Kanchan et al. (9) in their study, undertaken on Northern and Southern Indian population in 2009, have found the hand length to be $180.0 \mathrm{~mm}$ for males and $158.0 \mathrm{~mm}$ for females, and the hand width to be $72.0 \mathrm{~mm}$ and 64.0 mms for males and females respectively.

Ibeachu et al. (3) in their studies on a Nigerian population have reported hand length to be 190.5 $\mathrm{mm}$ for men and $176.5 \mathrm{~mm}$ for women. And hand width to be $85 \mathrm{~mm}$ for men and $79.6 \mathrm{~mm}$ for women. Khaled et al have reported hand length to be 194.7 $\mathrm{mm}$ for men and $181.3 \mathrm{~mm}$ for women and hand width $81.3 \mathrm{~mm}$ for men and $71.6 \mathrm{~mm}$ for women in an Egyptian population in 2011. Dean et al. (17) in their study in 2006 on a French population have reported hand length to be $190.8 \mathrm{~mm}$ for men and 


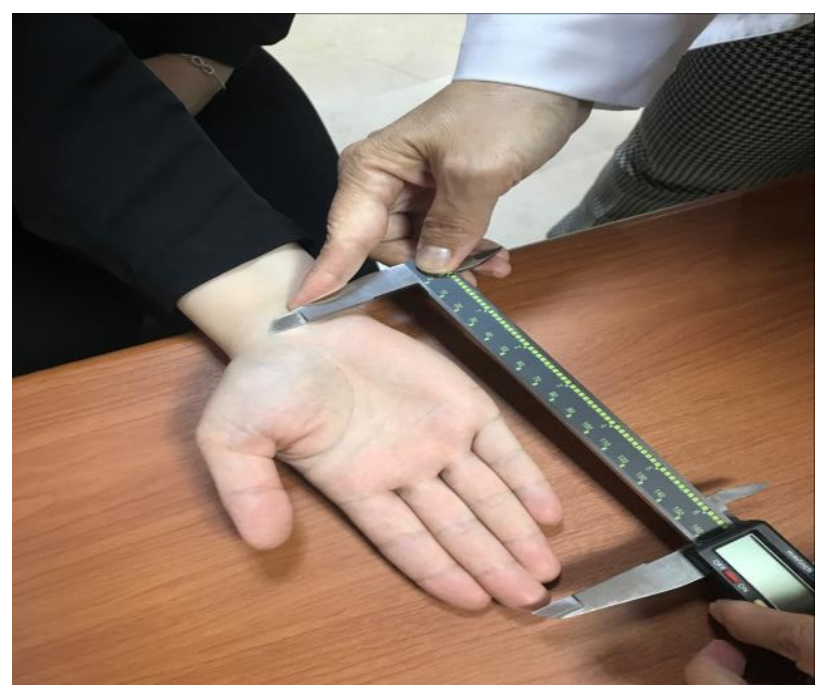

Fig. 1. Hand length measurement

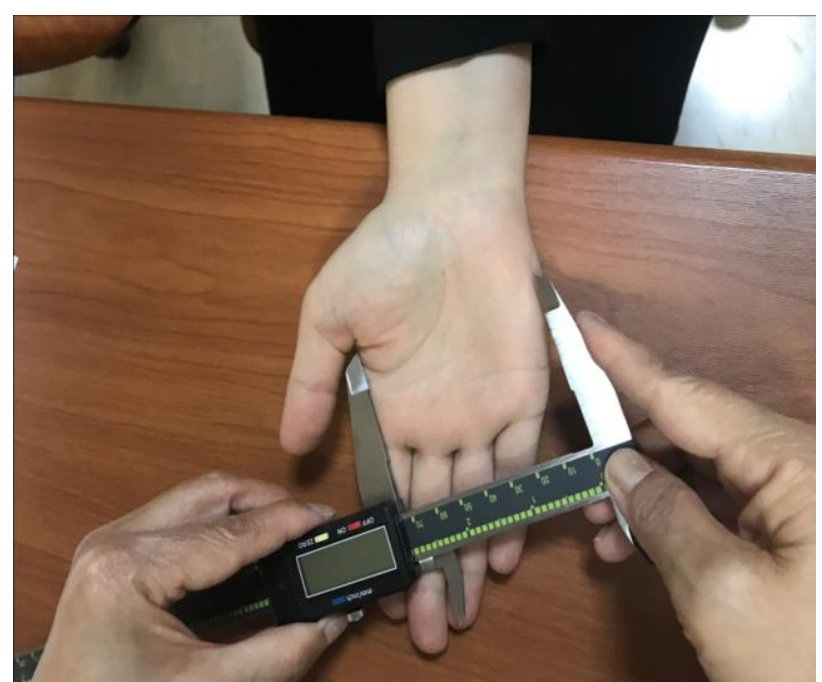

Fig.2. Hand width measurement

$173.5 \mathrm{~mm}$ for women and hand width to be $87.3 \mathrm{~mm}$ for men and $77 \mathrm{~mm}$ for women. Naabeel et al. (18) have found hand length to be $191.2 \mathrm{~mm}$ and 171.3 $\mathrm{mm}$ for men and women respectively in a Jordanian population in 2008. On a Turkish population in 2014 Karaday1 et al. (19) have reported hand length to be $192.0 \mathrm{~mm}$ for men and $178.5 \mathrm{~mm}$ for women and hand width to be $83.4 \mathrm{~mm}$ for men and $75.5 \mathrm{~mm}$ for women. Our study displayed hand length to be 183.9 $\mathrm{mm}$ for men and $169.7 \mathrm{~mm}$ for women and hand width to be 87.5 for men and $76.3 \mathrm{~mm}$ for women. As expected hand dimensions of men were greater than women in all these studies. These differences observed in hand dimensions between genders are used for gender verification through statistical models. There are also studies that have identified gender with various indexes formed after hand measurements being proportioned with each other $(13-20,21)$. The present study has proved that once again anthropometric measurements are highly specific to populations. Hand dimension is thought to be useful for gender verification like skeleton and many other sites of the body. We believe data observed in this study will help identification and gender verification studies on Turkish population

\section{References}

1. Brown PW. Psychologically Based Hand Disorders. In Hunter JM, Mackin EJ, Callahan AD ed (s). Rehabilitation of the Hand: Surgery and Therapy. St. Louis, USA: CV Mosby 1995; 9-19.

2. Dere F. Anatomi Atlas1 ve Ders Kitab1, Cilt 1, Nobel Kitapevi, Adana 1999.

3. Ibeachu PC, Abu EC, Didia BC. Antropometric Sexual Dimorphism of Hand Length, Breath and Hand Indices of University of Port-Harcout Students. Asian journal of medical Sciences 2011; 3: 146-150.

4. SC Jee, S Bahn, MH Yun. Determination of sex from various hand dimensions of Koreans. Forensic Science International 2015; 257: 521.e1-521.e10.

5. Kaur M, Singh B, Mahajan A, Khurana BS, Kaur A, Batra APS. Antropometric Measurements of Hand Length for estimation of stature in North Indians. IJABPT 2013; 4: 251-255.

6. Mandahawi Nabeel, Imrhan S, Al-Shobaki S, Sarder B. Hand Antropometry survey fort he Jordanian population. International Journal of Industrial Ergonomics 2008; 38: 966-976.

7. Sen J, Kanchan T, Mondal N, Krishan K. Estimation of stature from lenghts of index and ring fingers in a North-eastern Indian population. Journal of Forensic and Legal Medicine 2014; 22: 10-15.

8. Bures M, Gorner T, Sediva B. Hand Antropometry of Czech Population. Conference 2015; DOI:10.1109/IEEM.2015.7385814.

9. Kanchan T, Krishan K. Antropometry of hand in sex determination of dismembered remainsa rewiew of literatüre. J. Forensic Leg Med 2011; 18: 14-17.

10. Pal A, De S, Sengupta P, Maity P, Dhara PC. Estimation of stature from hand dimensions in Bengalee population, West Bengal, India Egyptian Journal of Forensic Sciences 2016; 6: 90-98.

11. AgnihotriA, Purwar B, Jeebun N. Determination of Sex by Hand Dimensions. The Internet J. Forensic Sci 2005; 1: 2.

12. Jasuja OP, Singh G. Estimation of Stature from hand and phalange length. JIAFM 2004; 26: 971-973. 
13. Khaled EA, Soheir AM, Maha AH, Eman AM. Determination of sex from hand dimensions and index/ring finger length ratio in Upper Egyptians. Egyptian Journal of Forensic Sciences 2011; 1: 80-86.

14. Barut C, Doğan A, Buyukuysal MC. Antropometric aspects of hand morphology in relation to sex and to body mass in a Turkish population sample. Homo 2014; 65: 338-348.

15. Onat P, Kan S, Nakkaş EÇ, Eryılmaz T, Kadayıfçı EC. El Boyutlarından Boy Tahmininde Sosyoekonomik Yapının Etkisi. In: Can P, editor. XV Öğrenci Sempozyumu Çalışma Grubu Sunumları; Ankara 2013.

16. Kanchan T, Rastogi P. Sex determination from hand dimensions of North and South Indians. Journal of Forensic Sciences 2009; 54 : 546-550.

17. Dean R Snow. Sexual dimorphism in upper Palaeolithic hand stencils. Antiquity 2005; 80: 390-404.
18. Naabel M, Salman SI, Al-Shobaki BS. Hand Antropometry Survey for The Jordanian Population. Int J Indus Ergonom 2008; 38: 966-976.

19. Karadayı B, Kolusayın RÖ. Adli Biyoloji. In: Adli Tip Ders Kitabı. İstanbul: Cerrahpaşa Tip Fakültesi Yayınları 2011; 477-90.

20. Kanchan T, Kumar GP, Menezes RG, Rastogi P, Rao PPJ, Menon A, Shetty BS, Babu YP, Monteiro FN, Bhagavath P, Nayak VC. Sexual dimorphism of index to ring finger ratio in South Indian adolescents. J Forensic Leg Med 2010; 17: 243-246.

21. Supare MS, Pandit SV, Bagul AS. Estimation of stature from hand length and hand breadth in medical students of Maharashtra, India. International Journal of Health\& Allied Sciences 2015; 4: 154-159. 